\title{
PLAGIARISM IN SCIENTIFIC PUBLISHING
}

\author{
Izet Masic \\ Faculty of medicine, University of Sarajevo, Sarajevo, Bosnia and Herzegovina
}

Corresponding author: prof. Izet Masic, MD, PhD. Faculty of medicine, University of Sarajevo, 71000 Sarajevo, Cekalusa 90, Bosnia and Herzegovina.

E-mail: imasic@lol.ba; izetmasic@gmail.com

\section{Editorial}

\section{ABSTRACT}

Scientific publishing is the ultimate product of scientist work. Number of publications and their quoting are measures of scientist success while unpublished researches are invisible to the scientific community, and as such nonexistent. Researchers in their work rely on their predecessors, while the extent of use of one scientist work, as a source for the work of other authors is the verification of its contributions to the growth of human knowledge. If the author has published an article in a scientific journal it cannot publish the article in any other journal $h$ with a few minor adjustments or without quoting parts of the first article, which are used in another article. Copyright infringement occurs when the author of a new article with or without the mentioning the author used substantial portions of previously published articles, including tables and figures. Scientific institutions and universities should,in accordance with the principles of Good Scientific Practice (GSP) and Good Laboratory Practices (GLP) have a center for monitoring,security, promo-

Most people say that is the intellect which makes a great scientist. They are wrong: it is character."

Albert Einstein, scientist

\section{INTRODUCTION}

\subsection{Ethical aspects of publishing}

Publications are the end-products of the scientific work, and their quantity and citability are keys to the promotion of scientists. Once published, a scholarly paper becomes a source for references, postpublication review and critique. To tion and development of quality research. Establish rules and compliance to rules of good scientific practice are the obligations of each research institutions, universities and every individual-researchers, regardless of which area of science is investigated. In this way, internal quality control ensures that a research institution such as a university, assume responsibility for creating an environment that promotes standards of excellence, intellectual honesty and legality. Although the truth should be the aim of scientific research, it is not guiding fact for all scientists. The best way to reach the truth in its study and to avoid the methodological and ethical mistakes is to consistently apply scientific methods and ethical standards in research. Although variously defined plagiarism is basically intended to deceive the reader's own scientific contribution. There is no general regulation of control of scientific research and intellectual honesty of researchers which would be absolutely applicable in all situations and in all research institutions. A special form of plagiarism is self-plagiarism. Scientists need to take into consideration this form of plagia-

contribute to the bulk of knowledge of evidence-based medicine (EBM), the paper should be credible (1). It should be based on optimal research design and reporting $(2,3)$.

Researchers and authors of scholarly papers have to follow ethical codes of Good Scientific Practice (GSP) $(4,5,6,7)$, primarily based of the principles of honesty and integrity (3). In the modern-day collaborative and multidisciplinary research, honesty of each and every author is becoming a pillar of trustworthy science. rism, though for now there is an attitude as much as their own words can be used without the word about plagiarism. If the authors cite their own research facilities already stated then they should be put in quote sand cite the source in which it was published. Science should not be exempt from disclosure and sanctioning plagiarism. In the fight against intellectual dishonesty on ethics education in science has a significant place. A general understanding of ethics in scientific research work in all its stages had to be acquired during the undergraduate course and continue to intensify. It is also important ethical aspect of the publishing industry,especially in small and developing economies, because the issuer has an educational role in the development of the scientific community that aspires to relish so. In this paper author describe his experiences in discovering of plagiarism as Editor-in-Chief of three indexed medical journals with presentations of several examples of plagiarism recorded in countries in Southeastern Europe. Key words: ethical dilemmas, scientific publishing, medical journals, plagiarism, self-plagiarism.

By claiming authorship of scholarly works, researchers get promotion and numerous other academic benefits. However, they also become responsible for what they publish and influence future publications, and science and education at large $(8,9,10)$.

Currently many learned associations provide and strongly advocate field-specific standards of research, ethical reporting and publishing aimed at preserving the integrity of science $(11,12,13)$. 


\subsection{Quoting and CITING references}

Researchers rely on the published data, and have to be skilled to selectively process these data, to incorporate previous knowledge into a new paper, and to distinguish original ideas and research results from already publicized ones. Authors are obliged to follow ethical, moral, and legal regulations acceptable by the scientific community $(2,9)$. To do so, they must properly cite relevant publications and quote borrowed published or unpublished ideas and words $(2,9,10)$. Simply, when an author copies others' text word for word, the borrowed passage should be enclosed in the quotation marks (inverted commas). The reader should be clearly informed over what is original and recycled from other sources $(2,9,14,15)$.

Current academic promotion and research funding are heavily dependent on the quantity of articles. 'Publication at Any Cost' and 'Publish or Perish' mantras adversely affect the whole research environment and cultivate recycled writing $(1,3)$.

It is absolutely unacceptable to republish a paper with minor changes, without referring to the primary publication, and to present it to the readership as a new source. In this case, the author may breach the copyrights of the publisher, holding all rights for distribution and republication of the primary source. The same applies not only to the verbatim copying of the text, but also to the borrowing of published tables, figures, and other graphical material, even those of the same author. It is also unacceptable to excessively rely on multiple published papers, even if these are properly paraphrased or summarized in a secondary publication (review, editorial). The readership deserves to find new points, ideas and original texts in each and every scholarly paper (14). This is why some leading publishers set limits of references for different types of papers.

\subsection{Good laboratory and scientific practice}

In accordance with the principles of GSP and Good Laboratory Practice (GLP), scientific and academic institutions should have units for monitoring research and development of the quality. The institutions should set policies and take responsibility for integrity of research reporting. This is particularly important for boosting potential of novice researchers.

The adherence to the codes of GSP, in turn, ensures the quality of education (16, 17, 18, 19). Reliable and evidence-based sources are increasingly extrapolating into medical practice guidelines, influencing human health. Accordingly, scientific misconduct may have farreaching detrimental consequences.

Historically, first attempts to tackle scientific misconduct and dishonesty were made in the U.S. in 1992 by launching the Office of Research Integrity (ORI). The organization's main tasks included promotion of scientific integrity, development of guidelines for scientific research, and investigation of allegations of misconduct, particularly in biomedicine (1). Based on the US model, many national bodies for ethics in science were established globally. As a result, science editors became familiar with multiple cases scientific dishonesty.

Another major step forward was the establishment of the UK-based Committee on Publication Ethics (COPE; 1997). COPE introduced scientific principles of fairness and developed a set of flowcharts specifically dealing with misconduct.

\subsection{Intellectual dishonesty in science}

Truth and trustworthy results are 'flesh and bones' of scientific research. To have trustworthy results and to avoid misconduct, researchers should use optimal study designs and follow ethical standards.

Scientific misconduct can be unintentional and intentional. The former is usually due to inappropriate use of research methodology, while the latter is a frank dishonesty and violation of ethical standards (intellectual dishonesty).

Misconduct can take the form of legal violations. Inappropriate authorship and research manipulations can be viewed as serious eth- ical and legal violations, subject to punishments of respective scientific and academic institutions $(1,3,17$, 18, 19).

Common causes of intellectual dishonesty in science are:

- All-pervasive 'Publish or Perish' mantra;

- Personal ambitions of poorly educated individuals;

- Vanity;

- Financial pressure.

The worst forms of scientific misconduct and intellectual dishonesty are:

- Falsification of the obtained data;

- Fabrication of the data;

- Plagiarism of ideas and words (stealing others' ideas, data, texts) $(1,3)$.

\section{PLAGIARISM}

\subsection{The definition and}

classification of plagiarism

The term plagiarism stems from the Latin word plagium, meaning kidnapping a man. It literary means theft, taking material authored by others and presenting as someone else' (19). Plagiarism of words and ideas can be unintentional and intentional (14). It is "the tendency of literary theft and illegal appropriation of other people's spiritual property in general" or generally "passing others' work as own" (20). As Miguel Roig from St. John's University (USA) described in several his published papers about plagiarism (20) “the journal's publisher, explains that plagiarism takes many forms, from passing off another 's paper as the author's own paper, to copying or paraphrasing substantial parts of another's prepare, without attribution to claiming results from research conducted by others". In all its forms, as Elsevier publisher edited, plagiarism constitutes unethical publishing behavior and is unacceptable (21).

Plagiarism dates back to the foundation of science communication as a discipline. According to the World Association of Medical Editors (WAME) strict definition, plagiarism is when six consecutive words are copied $(6,25), 7$ to 11 words are 
overlapping set of 30 letters (23).

Plagiarism is basically intended to deceive the reader's. Here we are reminded of the comment of Samuel Johnson, dealing with a manuscript that he sent for evaluation: "Your work is both good and original. Unfortunately the parts that are good are not original, and the parts that are original are not good". (23). "The modern concept of plagiarism as immoral and originality as an ideal emerged in Europe only in 18th century, particular with the Romantic movement, while in the previous centuries authors and artists were encouraged to 'copy the masters as closely as possible' and avoid 'unnecessary invention' (24).

Plagiarism of words can be divided into: a) the direct form - completely or partially copying of text, computer files, audio or video recordings without acknowledging primary source; b) mosaic form borrowing ideas and opinions from the original source, few words and phrases without citing this source; c) self-plagiarism - reuse of one's own work without quotation and permission to reproduce text (21, 22). Generally speaking, plagiarism is when someone uses others' ideas, statements, linguistic style and does not acknowledge intellectual originators (19). "Before the plagiarist taken as their own people's tables or text, today there is a growing interest in taking the ideas and concepts" $(24,25)$.

Unfortunately, digitalization made copy-paste plagiarism and inappropriate re-use of sources from the websites, online journals, and other electronic media widespread. "Within academia, plagiarism by students, professors, or researchers is considered academic dishonesty or academic fraud, and offenders are subject to academic censure, up to and including expulsion" and researchers and professors usually were punished for plagiarisms by sanctions ranging from suspension to termination with losing their credibility and perceived integrity (24).

\subsection{Prevention and detection of plagiarism and self-plagiarism \\ There are no universal regulations}

on plagiarism prevention suitable for all scientific and academic institutions (1). The International Committee of Medical Journal Editors (ICMJE) gave a detailed explanation of what is not a duplicate publication (25). COPE attempted to tackle the problem of plagiarism by recommending cooperation with research institutions and retraction of untrustworthy material (26).

In the U.S., ORI suggested sanctions for plagiarists in 1989. Since then, ORI has reported a constant rise of cases of misconduct and plagiarism (27).

If there is an instance of substantive plagiarism (copying more than $25 \%$ of the published source), the redundant manuscript should be withdrawn from the publication process and actions taken to inform respective institution(s). If plagiarism is surfaced after the publication, editors should retract the paper and inform the readership on misconduct (1). The respective COPE flowchart is helpful in this regard.

Ethical aspect of publishing is especially important for small and developing economies (17). The participation of scientists from Bosnia and Herzegovina in the global scientific communication entails the obligation of accepting international standards cite the sources used (9).

Authors should:

- Always follow rules of properly citing references, acknowledging ideas taken at conferences and formal/informal discussions;

- References must contain full bibliographic information;
- Each source cited in the text must be listed in the bibliography;

- Quotation marks should be used if more than 6 consecutive words are copied;

- Obtain permission from other authors/publishers to reproduce copyright-protected graphics or text;

- It should be also noted that plagiarism can now be detected electronically (e.g., by use of CrossCheck of iThenticate).

If an author reuses his/her own published text, quotation marks should enclose the recycled text with a citation to the primary source. This will allow avoiding accusations of self-plagiarism. It is possible to republish the data previously presented in the form of congress abstract, with a reference to the abstract. To avoid instances of self-plagiarism, publishers usually ask the 
authors to sign a statement of originality, and even this option does not prevent from instances of misconduct $(1,4,25,26)$ (Figure 3).

\subsection{Examples of dishonesty in science}

Cases of plagiarism have been known throughout history of mankind. It affected not only medicine, but many other disciplines. Mozart's masterpieces were copied by Sallieri. Shakespeare's poems were also plagiarized.

Perhaps the first reported cases of intellectual dishonesty are those from the U.S., related to John's Darsee and Robert Slutsky. Dr John R.Darsee, a young researcher in clinical cardiology, published many scientific papers and put names of faculty colleagues as co-authors, though most of them were not or were minimally involved in research ('honorary authors'). In 1981, colleagues and supervisors discovered fabrication of the published data, mostly from the years of studentship at Emory and Harvard Universities. More than 10 primary publications and 45 abstracts were retracted as a result of the investigation (27).

Robert Slutsky worked as a radiologist in University of California. He put names of numerous 'honorary' co-authors, but did not insist to be the first author in the bylines. An investigation found that 137 of its 77 publications were valid, 48 were questionable, and 12 were false $(8,28)$.

In our times, plagiarism reported even among politicians and state leaders, who plagiarized during the PhD writing. Also, this plague affected many doctorate and master theses, and regular articles in Bosnia and Herzegovina and some other countries of South Europe. A case of copying graphics from an American textbook into a doctorate thesis from Zagreb, Croatia is depicted in Figures 1.

An analysis of 1385 submissions to the Croatian Medical Journal revealed 28 cases of scientific misconduct (29). Ten cases were related to duplicate publication of the same results in different journals, eight cases of multiple submissions, and five cases of plagiarism $(18,29)$.

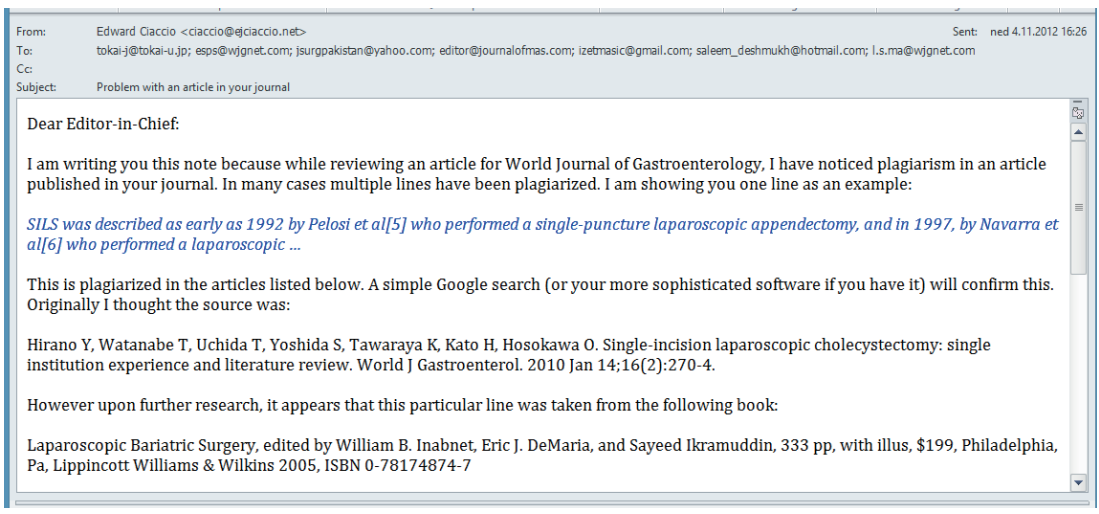

Figure 2. Letter to Editor-in-Chief of Medical Archives regarding plagiarism in published article

Interestingly, the first case of plagiarism in Croatia referred to one of the most productive Croatian scientists, who was accused for misconduct in a paper published 40 years ago. An investigation substantiated the case of plagiarism by a Croatian and a British researchers, who published their work in Acta Medica Iugoslavica. The case was closed after an apology from the Croatian author, who continued producing a large number of quality papers and became one of most cited author in his scientific field.

In another notorious case from Croatia, a group of undergraduate students reported that 86 pages of an American textbook were translated into Croatian and published without acknowledging primary textbook. An investigation confirmed that the accusations of plagiarism were correct. After decision of a public warning made by Court of Honor at Medical School, University of Zagreb author moved to another University.

In the former Yugoslav countries, number of plagiarism cases in textbooks, articles, monographs, scientific and professional articles is increasing. To their more intense detection helped database browser and some specially designed software for these purposes. The key reasons for the intense plagiarism is, how Serbian scientists mentioned in blogs on web sites, the lack of basic medical research, which are absent because less money is allocated for the research (28). But, also one of the key reasons is the newly introduced Bologna principle of studies that needs many experts to be involved in the teaching process and which significantly changed the selection criteria for teachers in teaching and academic titles.

Scientists in Serbia and Croatia with petitions stood up in defense of academic dignity against those who plagiarize in their papers the other authors. And I am also among those who are copied. However, as editor, I was able during 2012 to withdraw 5 articles from publishing because it was indicated to me by the reviewers or readers of articles about plagiarism and in one case by an author who was plagiarized and the article was published in the Medical Archives journal that I edited (Figure 2). In the former Yugoslavia before 1991 (the war in the Balkans) there were 140 indexed journals. Today there is only $1 / 3$ of that number, but the number of plagiarism increased four times. I think that this is a serious problem that should be addressed in the international academic community, because it is not only a question of credibility disrupted scientists from former Yugoslav countries, but also journals and indexing databases which stores plagiarized articles. This problem is difficult to solve because a large number of plagiarism has done with people involved in political decisionmaking in these countries.

To detect plagiarism more easily, during the 80' of last century started the development of software to detect academic and scientific plagiarism. Academic plagiarism is more easily detected by the software as Turnitin and SafeAssign and scientific plagiarism with CrossCheck and eTBlast software. The software consists of algorithms to detect similarities, associated databases and 


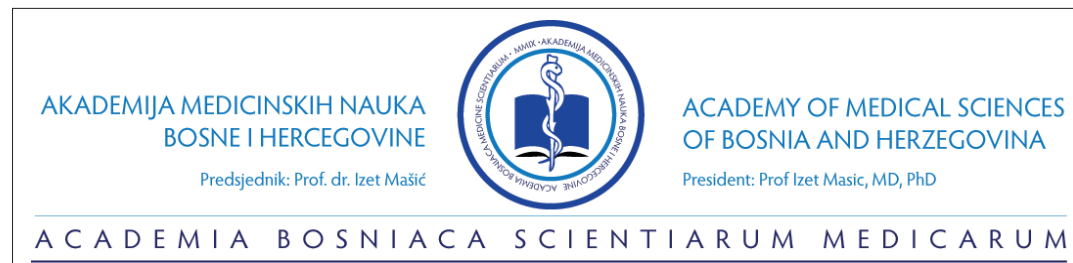

\section{COPYRIGHT ASSIGNMENT FORM}

This Agreement is made with Author(s) of the article and Publisher of Medical Archives, Materia Socio Medica and Acta Informatica Medica.

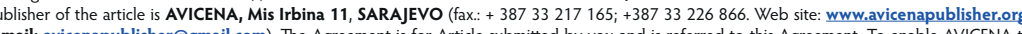
E-mail: avicenapublisher@gmail.com). The Agreement is for Article submitted by you and is referred to this Agreement. To enable AVICENA to publish the Article in the Journals the ownership of copyrights must be established. Please fill form and return copy to address given below.

This Article can not be published without signed Agreement with AVICENA d.o.o.

AUTHOR'S WARRANTY

\section{Name: \\ Address: \\ Author's names \\ Article title}

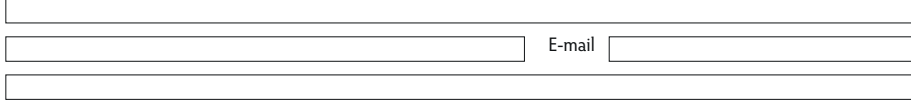

In consideration of publication of the Article in above Journal, thereby warrant and consent

a. that this Article is original work, has not been published before and is not being consider for publication elsewhere in its final form either in printed or electronic form

b. that I have obtained permission from copyright holders to reproduce material in the Article, and that I have acknowledged the resource that this Article contains no violation of any existing copyright or other third party right or any material of an obscene, indecent, libelous or other unlawful nature and that to the best of my knowledge this Article does not infringe the rights of others;

d. that I will indemnify and keep indemnified the AVICENA, d.o.o. against all claims and expenses arising from any breach of this warranty and the

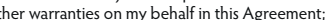

that in case of Article with many authors I have obtained copyright assignments from all co-authors in writing, and authorization to enter into this Agreement on their behalf and that all have read and agreed to the above warranties;

f. That I and all co-authors of article will pay the amount 250 Euros for all journals (Med Arh, Acta Inform Med, Mat Soc Med) by signed submission of the article for administrative purposes and reviewers. If article not accepted for publication, half amount of money will be returned to authors after rejection. The amount has to be paid by using PayPal System (follow instructions on www.avicenapublisher.org) or to the account of AVICENA DOO SARAJEVO, IBAN No 1020500000020077 Beneficiary's Bank: UNIONBANKA DD Sarajevo, SWIFT Code UBKSBA22 via Deutsche Bank AG, Frankfurt AG Frankfurt/Main (DEUTDEFF) or Commerzbank AG Frankfurt/Main (COBADEFF) or KBC BANK NV-BRUSSELS (KREDBEBB), for period in that the Article will be published.

Author:

Date:

Copyright assignment

In consideration of the publication of this Article in the Journal, I hereby assign to AVICENA, d.o.o. the copyright for the period of copyrights duration and for all renewals, extension, revisions and revivals together with all acquired rights of action throughout the world in any form and in any language retain all proprietary right other then copyright, such as patent or trade mark rights and rights to process or procedure described in Article In signing this form I confirm that all of co-authors agree with publishing of this Article in Journal If some of parts of Article are protected by copyright and copyright holder agrees that can be published in this Article, the source of this text must be cited.

Author:

Co-author 3.

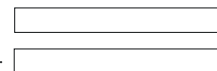

Co-author

Co-author 4.

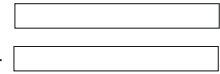

Co-author 2 Co-author 5

Figure 3. Copyright Assignement Form dowloaded from www.avicenapublisher.org

web sites by which it compares the article. This software packages helps to identify plagiarism but they also have flaws and still needs improvements (32).

"Plagiarism is not a crime per se but is disapproved more on the grounds of moral offence" (24). Honesty in science is the very basis of its existence. Even a shadow of dishonesty may devalue the work and lead to the loss of respect $(29,30,33,34)$.

\section{CONCLUSION}

Scientific and academic institutions should have established units for monitoring, promotion and research development. Science should not be exempt from disclosures and sanctions due to plagiarism.
Scientists from Bosnia and Herzegovina take part in the global scientific communication, and need a body to facilitate scientific research, to adopt ethical standards and guidelines.

There is a dilemma: who, on what basis (criteria, standards, rules), when and how should declare someone a plagiarist. Then, which institutions or which scientific body committee at the national or international level, when plagiarism is proven, can someone sanction and what are the sanctions.

It is necessary to work on mechanisms for early detection of plagiarism, and relevant software should be used by all reputed journals.

At an international level, a data- base of all cases of plagiarism should be launched with disclosure of all names of blacklisted plagiarist.

\section{Conflict of interest: none declared}

\section{REFERENCES}

1. Masic I. Ethical aspects and Dilemmas of Preparing, Writing and Publishing of the Scientific Papers in the Biomedical Journals. Acta Inform Med. 2012; 20(3): 141-148. doi:105455/aim.2012.20.141-148.

2. Masic I. How to Search, Write, Prepare and Publish the Scientific Papers in Bimedical Journals. Acta Inform Med. 2011; 19(2): 68-79. doi:10.4555/ aim.2011.19.68-79.

3. Wager E, Kleinert S. Cooperation Between Research Institutions and Journals on Research Integrity Cases: Guidance From the Committee on Publication Ethics (COPE). Acta Inform Med. 2012 Sep; 20(3): 136-140. doi: 10.5455/ aim.2012.20.136-140.

4. International Committee of Medical Journals Editors. Uniform Requirements for Manuscript Submitted to Biomedical Journals: Writing and Editing for Biomedical Publication. (Updated October 2008). Available: http:// www.icmje.org/.

5. Council of Science Editors. CSE's White Paper on Promoting Integrity in Scientific Journal Publications. Editorial policy committee (2005-2006). Available: http://www. Council Science Editors.org

6. World Association of Medical Editors. WAME recommendations on Publication Ethics and Policies for Medical Journals. Available: http://www.wame. org/resources/ethics-resources.

7. Committee On Publication Ethics. COPE. Code of Conduct and Best Practice Guidelines for Journal Editors. Available: http://publication.

8. Savic J. Intelektualno nepoštenje u nauci. U: Brkic S, Vuckovic-DekicLj, Bogdanovic G. Publikovanje u biomedicini. Ortomedics, Novi Sad, 2006: 32-34.

9. Masic I, Mornjakovic Z, Šuško I, Cosovic E. Citiranje i navodjenje literature u biomedicini. Acta Inform Med. 2004, 12(3-4): 91-95.

10. Šamic M. Kako nastaje naucno djelo. Uvodjenje u metodologiju i tehniku naucnoistraživackog rada - opšti pristup. 8.izd. Svjetlost, Sarajevo, 1990: 170.

11. O'Dowd A. Peer review system needs thorough evaluation. MPs hear. BMJ. 
2011; 342: d3046. doi: 10.1136/bmj. d3046.

12. Moher D, Weeks L, Ocampo M. et al. Reporting guidelines for health research: a review. Journal of Clinical Epidemiology. 2011; 64(7): 718-742. doi. 10.1016/j.clinepi.2010.09.013.

13. Drazen JM, Van der Weyden MB, Sahni P, Rosenberg J, Marusic A, Laine C, Kotzin S, Horton R, Hébert PC, Haug C, Godlee F, Frizelle FA, de Leeuw PW, DeAngelis CD. Uniform format for disclosure of competing interests in ICMJE journals. N Engl J Med. 2009; 361(19): 1896-1897.

14. Habibzadeh F, Marcovitch H. Plagiarism: the emperor's new clothes. European Science Editing. 2011; 37: 67-69.

15. Habibzadeh F, Shashok K. Plagiarism in scientific writting: words or ideas. Croatian Medical Journal. 2011; 52(4): 576-577. doi: 10.3325/cmj.2011.52.576.

16. Gasparyan YA, Ayvazyan L, Kitas DG. Biomedical journal editing: elements of success. Croatian Medical Journal. 2011; 52: 423-428. doi: 103325/cmj.2011.52.423.

17. Marusic A. Importance of Ethical Publishing in Developing Countries. Acta Inform Med. 2012; 20(1): 4. doi: 105455/ aim.2012.20.4-4.

18. Marusic A. Problems of editors with au- thorship in small medical journals. The International Journal of Occupational and Environmental Medicine. 2011; 2(3): 130-132.

19. Kljajic B. Rjecnik stranih rijeci. Nakladni zavod, Zagreb, 1990: 1052.

20. Roig M. Avoiding unethical writing practices. Food and Chemical Toxicology. 2012; 50: 3385-3387.

21. Elsevier, 2012. Authors Rights and Responsiblities. Publishing Ethics, Duties of Authors, Originality and Plagiarsim. http://www.elsevier.com/vps/find/authorsview.authors/rights. Accessed November 15, 2012.

22. World Assotiation of Medical Editors (WAME) Recommendations on Publication Ethics Policies for Medical Journals, Arch Med Res. 2004; 35: 361-367.

23. Amstrong JD. Plagiarism what is it, whom does it offend, and how does one deal whit it? Am J Roentgenol. 1993; 161: 479-484.

24. http://www.en.wikipedia.org/Plagiarism. Accessed Nov 15, 2012.

25. Committee On Publication Ethics. COPE. Code of Conduct and Best Practice Guidelines for Journal Editors. Available: http://publication ethics.org/ resources/guidelines.

26. http:/www.ori.dhhs.gov
27. http:/ccnmtl.columbia.edu/projects/rcrmisconduct/fondation/index.html

28. Peticija 1.000 srpskih naucnika. Falsifikatima do zvanja. http:/www.rtv.rs/sr_ lat/drustvo/peticija. Accesed November 25th 2012.

29. Marusic M, Katavic V, Hren D. Znanstveno-istraživacka cestitost. U: Marusic M. (urednik). Uvod u znanstveni rad u medicini. Zagreb, Medicinska naklada, 2004

30. Hansen TW. Neonatal jaundice and scientific fraud in 1804. Acta Paediatrica. 2002; 91: 1135-1138.

31. Neale AV, Northrup J, Dailey R, Marks E, Abrams J. Correction and use of biomedical literature affected by scientific misconduaction. Eng Ethics. 2007; 13: 5-24.

32. Lampert S, Pupovac V, Petrovecki M. Racunalni programi i programske usluge za tkrivanje plagiranja u znanosti i obrazovanju. MEDIX. 2012; 18(9899): 123-127.

33. Shamin T. The latest developments in plagiarism detection in medical literature. European Science Editing. 2012 May; 38(2): 56.

34. Bilic-Zulle L. Znanstvena cestitost temelj postojanja i razvoja znanosti. Biochemia Medica. 2007; 17(2): 143-150..

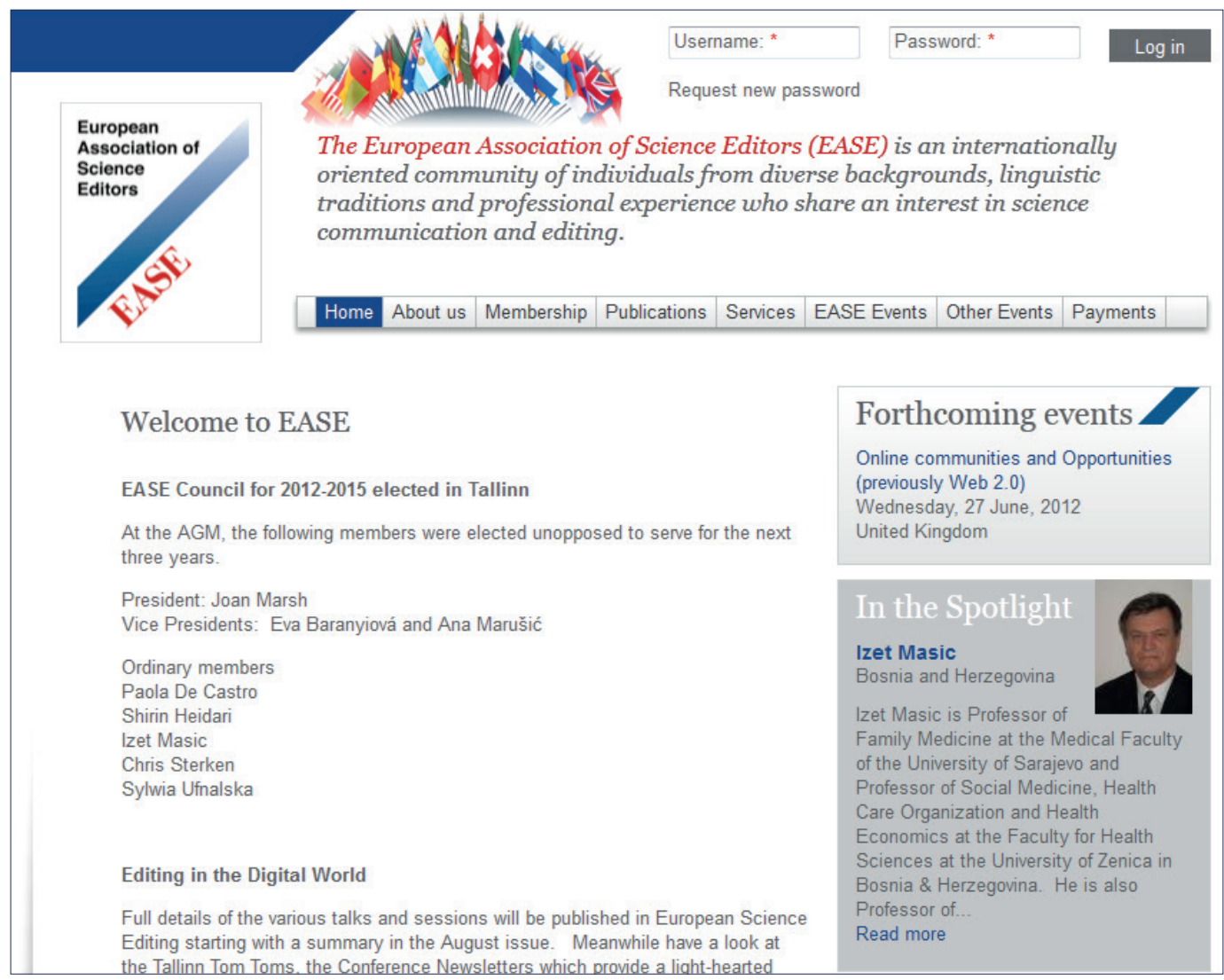

